$\mathrm{K}$

51,13

98

Received 5 August 2021

Revised 16 October 2021 8 November 2021

Accepted 15 November 2021

\section{Performance mapping in two-step cluster analysis through ESEG disclosures and EPS}

\author{
Dorina Nicoleta Popa, Victoria Bogdan, Claudia Diana Sabau Popa and \\ Marioara Belenesi \\ Department Finance-Accounting, Faculty of Economics Sciences, \\ University of Oradea, Oradea, Romania, and \\ Alina Badulescu \\ Department Economics and Business, Faculty of Economics Sciences, \\ University of Oradea, Oradea, Romania
}

\begin{abstract}
Purpose - The purpose of this work is twofold. First, looks to identify the main homogenous groups of companies after environmental, social, economic and governance (ESEG) disclosures, non-financial statement and earnings per share (EPS), and second investigates the connection between variables.

Design/methodology/approach - Using financial and non-financial information from annual reports of private listed companies, the authors performed two-step cluster analysis (TSCA) in the first stage of the research, followed by parametric, nonparametric correlation analysis, as well as regression analysis based on panel data, in the second stage.

Findings - Results of TSCA revealed a cluster of companies with good financial and non-financial outcomes and a cluster of companies with poor performance. The performance dynamics showed a slight improvement during the period for few companies and composition analysis of clusters by industries through KruskalWallis test highlighted differences between clusters, only for 2017. The main findings confirm a direct, although weak in intensity but statistically significant correlation between ESEG disclosure index, its sustainability component and financial performance (FP), valid for the entire period. Also, the results showed a direct link of low intensity to average, but statistically significant between the non-financial statement and EPS, valid only for 2017 and 2018.

Research limitations/implications - The results indicate mixed findings which invites further in-depth research. Limits of the study can be found in selected indicators and the short period of time analyzed. However, the practical implications are worth considering from the perspective of finding new managerial tools that can better shape the relationship between ESEG disclosures and FP.

Practical implications -ESEG Dindx can be an instrument for managers that can optimize the link between the FP of companies and its sustainable development.

Social implications - ESEG Dindx measures the disclosure degree of ESEG information by the companies listed on Bucharest Stock Exchange (BSE). The main findings of the work confirm a direct, although weak in intensity but statistically significant correlation between ESEG disclosure index, its sustainability component and FP, valid for the entire period.
\end{abstract}

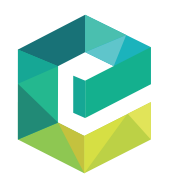

Kybernetes

Kybernetes
Vol. 51 No. 13, 2022 pp. $98-118$

Emerald Publishing Limited 0368-492X

DOI 10.1108/K-08-2021-0672
(C) Dorina Nicoleta Popa, Victoria Bogdan, Claudia Diana Sabau Popa, Marioara Belenesi and Alina Badulescu. Published by Emerald Publishing Limited. This article is published under the Creative Commons Attribution (CC BY 4.0) licence. Anyone may reproduce, distribute, translate and create derivative works of this article (for both commercial and non-commercial purposes), subject to full attribution to the original publication and authors. The full terms of this licence may be seen at http:// creativecommons.org/licences/by/4.0/legalcode

The authors would like to express our thanks to anonymous reviewers who have contributed to improve this article.

Funding: The publication fee for this article is supported by the scientific research budget of the University of Oradea.

Disclosure statement: The authors do not have any competing financial, professional, or personal interests from other parties. 
Originality/value - This study adds value to the existing literature by the proposed research framework, design of ESEG Dindx and the way correlations between variables were investigated.

Keywords Performance, Disclosure, ESEG information, EPS

Paper type Research paper
Performance mapping through ESEG $\operatorname{Dindx}$

\section{Introduction}

Modern reporting is no longer limited to classical financial information but also extends to non-financial information. Thus, the disclosure degree of environmental, social, economic and governance (ESEG) information is a frequently investigated topic in correlation with performance indicators, as other studies revealed that financial performance $(\mathrm{FP})$ is a significant indicator of the financial health of companies (Ştefan, 2016; Sabău-Popa et al., 2020) and that it is influenced by the information disclosure policy. The use of integrated reporting (IR) can lead to increased profitability of companies (Marjanova et al., 2017), while the analysis of profitability indicators and other financial indicators in correlation with nonfinancial variables may facilitate the ranking of companies.

Previous studies conducted on Romanian companies listed on the Bucharest Stock Exchange (BSE) (Dospinescu and Dospinescu, 2018, 2019) or on SMEs (Sabău-Popa et al., 2020) have focused mainly on investigating FP using composite indicators, while others have been concerned with examining the relevance of non-financial information in the sustainable reporting of Romanian companies (Man and Bogeanu-Popa, 2020). In their study on the examination of disclosure practices of Romanian companies in the agricultural and manufacturing industry before adopting mandatory non-financial reporting requirements, Imbrescu and Hategan (2017) showed that a relatively small number of companies are aware of the importance of disclosing sustainability indicators and highlighted that the highest degree of voluntarily disclosed information is for CSR registered in the food industry, which also reports a good FP. In a comparative study conducted on oil polluting entities listed on the BSE and the Athens Stock Exchange, Artene et al. (2020) inventoried the changes imposed by the requirements of Directive 2014/95 in the reporting of environmental information and investigated the correlations between the reported CSR practices and those related to environmental protection.

As public interest has grown in recent years in terms of transparency and disclosure policies and the assessment of the influence of environmental, social and governance information has led to new configurations of reporting and performance measurement, this study was initiated out of the desire to monitor the disclosure behavior of Romanian private listed companies in terms of non-financial information, in dynamics, before and after the implementation of the EU Directive 2014/95 requirements in the national regulations (Order no. 1938/2016 and Order no. 3456/2018), in correlation with measuring FP through the earnings per share (EPS) profitability indicator. In this sense, the chosen period for investigation is 2017-2019. In our approach to fill in the existing research gap on disclosure behavior measurements in correlation to FP, we looked to answer the following research questions:

$R Q 1$. How can companies be classified by their disclosure and reporting behavior of nonfinancial information through a specific report/statement, in correlation with EPS as a profitability indicator, and which are the changes in this behavior?

$R Q 2$. How does the relationship between the non-financial disclosure index, non-financial statement and EPS affect the performance of companies?

The paper is organized as follows: a theoretical background is presented in the section following the introduction, and then data and methodology are revealed; results are discussed and highlighted after statistical data processing, and conclusions and implications are underlined in the last section. 
$\mathrm{K}$

51,13

100

\section{Theoretical background}

2.1 Theories that support the nexus ESEG disclosures-financial performance

Additional explanations in reporting information beyond those required by law are provided by some of the theories that connect business performance information (Jensen and Meckling, 1976; Alsayegh et al., 2020; Rahman and Alsayegh, 2021). Below is presented a brief description of theories that constitute the foundations of correlation analysis between ESEG disclosure degree and $\mathrm{FP}$ of companies.

2.1.1 Legitimacy theory. All stakeholders are interested in non-financial and sustainability information provided by companies. Also, non-compliance with social, environmental, transparency and business ethics regulations and governance rules can seriously damage performance and reputation, thus affecting organizational legitimacy, as well as sustainable financial development (Guthrie and Parker, 1989; Tilling, 2004; Deegan, 2006; Rahman and Alsayegh, 2021). The most common way to remedy the legitimacy gaps is to increase the disclosure degree of ESEG information (Deegan, 2006, 2019; Rezaee, 2017; Alsayegh et al., 2020). Therefore, this theory is often used as a mechanism to support companies in implementing, developing and reporting mandatory and voluntary ESEG information to convince their communities that their businesses are socially responsible.

2.1.2 Stakeholder theory. This theory shows that managers must make decisions that serve the interests of all stakeholders. ESEG actions that lead to increase disclosure generate synergies as they create conflicts, too (Rezaee, 2017). Stakeholder theory conveys the idea that by ESEG practices and sustainable ways to increase performance, responsibilities towards the company are fulfilled, environmental obligations are fulfilled and the company's reputation and prestige are improved, which leads to an increase of its value (Cormier et al., 2005; Campbell, 2007; Clarkson et al, 2011b; Weber, 2008). However, it is also true that sustainable development actions can lead to changes in the allocation of resources and prioritize meeting the information needs of certain stakeholders, which can often lead to conflicts. Thus, the pressure on managerial decisions increases and results in a tendency to invest in projects that favor long-term sustainable financial development (Rezaee, 2017).

2.1.3 Signaling theory. Information disclosure signals about a company's business development and influences the behavior of stakeholders. The channels of communication on FP and sustainable development are represented by mandatory and voluntary financial and non-financial reports, signaling through them aspects that differentiate companies from other competitors (Rezaee, 2017). For instance, public interest companies generally practice ESG activities to send a positive message and for those that innovate ecologically and have higher ESG scores, green signals are received positively by stakeholders improving green performance ( $\mathrm{Xu}$ et al., 2021). Despite their evidence supported by signaling theory, correlations between voluntary disclosure of non-financial information and capitalization of emitted signals are unclear (Connelly et al., 2011; Dainelli et al., 2013; Alsayegh et al., 2020).

2.1.4 Voluntary disclosure theory. Companies disclose additional information as a means of communication between management and shareholders, thus reducing the cost of capital and information asymmetry generated by the agency's theory (Grinblatt and Hwang, 1989; Alsayegh et al.,2020). Voluntary reporting can supplement mandatory reporting on a company's performance and can also send signals about future expected FP (Healy and Palepu, 2001). Social, political and environmental pressures have led to increased disclosure of ESEG information in response to these constraints (Roberts, 1992; Cho et al., 2015). The consequence of the implementation of Directive 2014/95/EU in the national legislation can be translated by the conversion of non-financial information previously voluntarily disclosed by public interest entities, into mandatory information to increase the accountability of companies to stakeholders (Manes-Rossi et al., 2018).

\subsection{Prior studies}

In the context of IR and the legal framework imposed by Directive 2014/95/EU, there is a growing interest in empirical studies investigating the relationship between reporting and 
disclosure of non-financial information and FP. To include the present study in the current state of knowledge, we mainly examined studies carried out in the last two decades aiming to investigate ESEG indicators in relationship with corporate performance. Thus, we observed that Bătae et al. (2021) found a significant positive relationship between emission reductions and ROA of banks, but a negative relationship between lagged product responsibility and ROA, change in management, oversight score and change in ROA. Horvathova (2010) proved that adequate time coverage is important to establish a positive link between environmental and FP, arguing that it takes time for environmental regulation to materialize in FP. Huang (2021) argued a positive but very modest economic relationship between ESG performance and FP, the relationship between environmental and FP proved to be stronger than performance measured in social and governance terms. As we noticed, studies that approach this topic through multilevel analyses are likely to obtain more feasible results. Kuo et al. (2021) traced ESG performance and short-term FP indicators and proved that airlines should give priority to the selection of key performance indicators for CSR implementation towards sustainability. Analyzing the effect of corporate controversies on FP, with the role of the positive moderator of ESG practices, Nirino et al. (2021) recorded a relevant negative relationship. Nevertheless, the positive moderating effect of ESG practices has not been confirmed.

An intriguing approach is found in the work of Gaganis et al. (2021) which developed a composite indicator of social, environmental and $\mathrm{FP}$ and created a holistic evaluation framework for banks to enhance their role as financial actors. Based on an empirical assets pricing model, Broadstock et al. (2021) analyzed the role of information in the cross-section of ESG scores, during COVID-19 compared to the non-COVID-19 period and found that COVID-19 had a strong and negative impact on the market. Is relevant also, that performance indicators are becoming more specific, studies like the one done by Boloş et al. (2021) propose the use of neutrosophic fuzzy triangular numbers for financial assets to solve optimization issues.

Petitjean (2019) compared the nature of the relationship between environmental and FP in the 2008-2009 crisis and proved that emission reduction or climate change policies in large US companies do not generally appear to be associated with better FP. Boakye et al. (2021) examined the inverted U relationship between environmental management and SMEs FP and found that a moderate adoption of environmental practices is likely to increase FP. While MdNor et al. (2016) aimed to investigate the link between environmental disclosure and FP and revealed mixed results, Qiu et al. (2016) found that past profitability determines current social disclosures and companies that make higher social disclosures have higher market values. The link between environmental disclosures and green performance analyzed in prior empirical studies (Cho and Patten, 2007; Clarkson et al., 2011; Farag et al., 2015; Hummel and Schlick, 2016; O’Donovan, 2002; Luo, 2019; Xie et al., 2019) was investigated based on major theoretical streams, and a negative correlation was argued based on stakeholder and legitimacy theory, while a positive correlation was demonstrated through voluntary disclosure and signaling theory. Thus, Siddique et al. (2021) showed that environmental performance positively affects carbon disclosures, and disclosure of carbon emissions, in turn, positively influences long-term FP, as evidenced by the signaling theory.

Borodin et al. (2019) argued that the impact of publishing non-financial information has a longer-term effect on ROA and more on increasing the Q-Tobin ratio. The cross-sectional analysis shows a more accurate picture of how non-financial information affects financial indicators. Thus, non-financial statements had a significant positive effect on Q-Tobin growth next year, only in sectors such as commodities and utilities. Pavlopoulos et al. (2019) examined the relationship between IR and market valuation and found a statistically positive and significant association between the quality index of IR and ROA. Comparative studies of non-financial reporting practices ex ante and ex-post European Directive were also carried out by Tarquinio et al. (2020), Venturelli et al. (2020) and Nicolò et al. (2020) with controversial results such as the increase in the number of non-financial reports to the detriment of data
Performance mapping through ESEG $\operatorname{Dindx}$ 
$\mathrm{K}$

51,13

102

comparability or the non-stimulating effect of mandatory disclosure requirements on companies' disclosure behavior, the level of disclosure through integrated reports remaining relatively the same. National accounting regulations (Order 3456/2018) starting with 2019 require the mandatory publication of a non-financial statement by all entities with more than 500 employees, without making a difference between entities that report according to national regulations and those that fall under IFRS.

In our effort to include our study among those investigating the disclosures of nonfinancial information and their impact on $\mathrm{FP}$ we have developed several hypotheses. We used a composite disclosure index (ESEG Dindx) to measure the average disclosure degree on ESEG information and EPS profitability indicator to measure FP. Also, we looked upon the disclosure behavior through non-financial statements in correlation with EPS indicator.

H1. There is a positive correlation between the ESEG Dindx and EPS.

H1a. There is a positive correlation between the sustainability component of ESEG Dind $x$ and EPS.

H1b. There is a positive correlation between the economic component of ESEG Dindx and EPS.

H1c. There is a positive correlation between the governance component of ESEG Dindx and EPS.

H2. There is a correlation between the existence of non-financial statements and EPS.

H3. There is a significant impact of ESEG Dindx on EPS.

H3a. There is a significant impact from the sustainability component of ESEG Dindx on EPS.

$H 3 b$. There is a significant impact from the economic component of ESEG Dindx on EPS.

H3c. There is a significant impact from the governance component of ESEG Dindx on EPS.

H4. There is a significant impact of the non-financial statement on EPS.

\section{Data and methodology}

\subsection{Data}

Data collected and analyzed are financial information related to EPS indicator and nonfinancial information consisting of ESEG variables. The investigated period was 2017-2019 using as a primary source of information the annual reports of 60 private companies listed on the BSE. The period was selected to examine the disclosure behavior of non-financial information by Romanian companies. Data were collected manually from the financial statements and non-financial and sustainability reports of selected companies. The selection criteria of companies were: continuity of activity; annual reports published on companies' websites; financial statements published for 2017-2019 and the non-financial statement or the sustainability report published for the same years. Eight industries from the private sector of the economy were analyzed, the largest share (65\%) of companies can be found in the manufacturing industry.

To measure FP, the EPS indicator was selected, being one of the classic profitability indicators frequently used to evaluate the performance of Romanian companies. EPS was calculated as the ratio between net income minus preferred dividends and the weighted average common stock outstanding, using information from the profit and loss account and the explanatory notes. To calculate the ESEG disclosure index (ESEG Dindx), scores were 
used to measure the disclosures and hence the aggregate average disclosure index was constructed as a ratio between the sum of scores given for the disclosed information and the number of quantified non-financial information. Score 1 was assigned for non-disclosure of information and score 4 for disclosure and presentation of detailed information. In total, 12 categories of non-financial information were noted, of which: one category of environmental information; 3 categories of social information; 5 categories of economic information and 3 categories of governance variables. We considered the disclosed environmental and social information as a sustainability component of ESEG Dindx.

\subsection{Methodology}

The research was carried out in two stages starting from the relationship between ESEG variables and company performance, supported by the theories described previously (Figure 1). If in the first stage we aimed to group companies in clusters according to the disclosure index of non-financial information and FP, through a cross-sectional analysis by industries, in the second stage we aimed to statistically test the correlations between the variables that express performance through non-financial and financial variables.

3.2.1 First stage. This stage aims to identify the main homogenous groups of companies in terms of ESEG Dindx, the existence of non-financial statements, but also taking into account the FP assessed by EPS, at the level of 2017-2019, to examine whether there are companies that have migrated from one cluster to another improving their overall performance. The results of clustering analysis will be evaluated from the perspective of industry type. The hypothesis of significant differences between clusters in terms of the industry was tested using the Kruskal-Wallis test. ESEG Dindx should take values from 0 to 100 being together with EPS numerical variables, while the existence of a non-financial statement is a dummy variable that takes the value 1 if the non-financial variables were presented distinctly in the statement and 0 otherwise. The industry is a polychotomous variable with 8 categories, one for each chosen branch. Cluster analysis is a tool used in the development of composite indicators to group information based on their similarity to different individual indicators. The two-step cluster analysis (TSCA) has been selected for the benefits it offers. Thus, it can be applied to both continuous and categorical variables; the optimal number of clusters can be determined automatically based on informational criteria. TSCA has two limitations: how it addresses the missing values and the influence of the order of records in the results of cluster analysis. TSCA uses an algorithm that allows grouping a large number of observations into

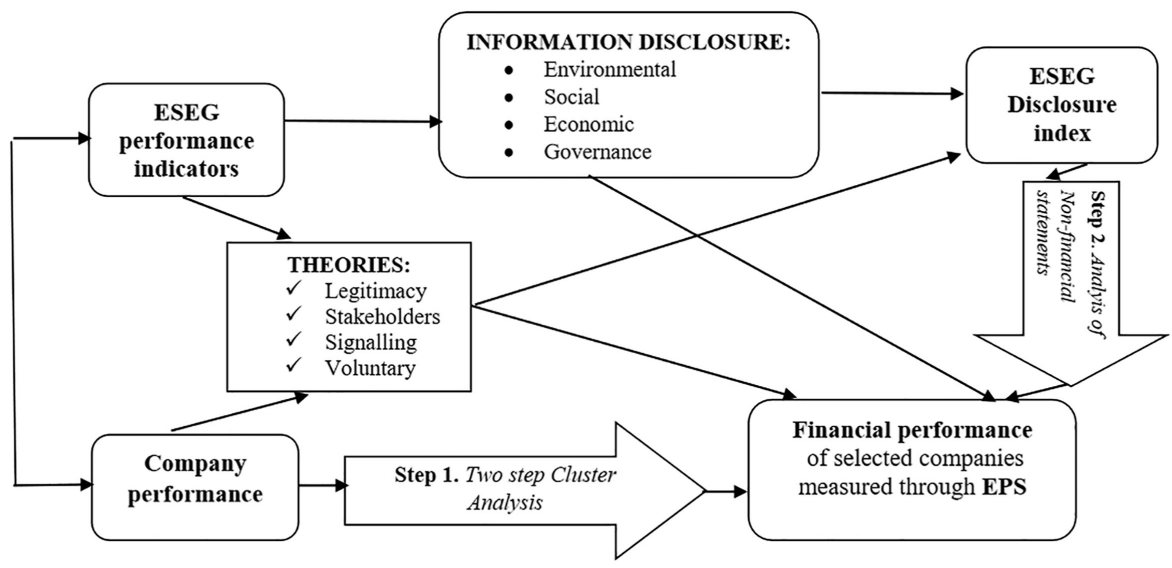

Performance mapping through ESEG $\operatorname{Dindx}$

103 
$\mathrm{K}$

51,13

104

natural groups. The clustering process is based on a similarity criterion that involves the calculation of distances. As shown by Andreano et al. (2020), it is more appropriate to find homogenous local clusters with similar probabilities to be in default than to aim at estimating a global model for the entire sample.

3.2.2 Second stage. This stage aimed to investigate the relationship between ESEG Dindx, the existence of non-financial statements but also companies' FP, using parametric (Pearson), nonparametric correlation analysis (Spearman, Kendall), Mann-Whitney test to investigate significant differences, as well as regression analysis based on panel data, with the help of STATA 14 software. Following Beleneşi et al. (2021) analysis of non-financial disclosure metrics and design of ESEG Dind $x$ by applying principal component analysis we found that three main components are included in the construction of the composite index, a sustainability component that contains environmental, personnel and waste management information, an economic component related to transparency of trade policies and a governance component including social responsibility, board and executive management issues and other corporate governance information. Therefore, we construct the general form of the panel data regression model as

$$
\begin{aligned}
& E P S_{i t}=\alpha_{0}+\alpha_{1} \cdot E S E G_{i t}+\alpha_{2} \cdot \text { non }_{\text {fin }} \text { declit }_{\text {it }}+\varepsilon_{i t} \\
& E P S_{i t}=\alpha_{0}+\alpha_{1} \cdot \text { sust_comp }_{i t}+\alpha_{2} \cdot \text { non }_{\text {fin }_{\text {dec }} l_{i t}}+\varepsilon_{i t} \\
& E P S_{i t}=\alpha_{0}+\alpha_{1} \cdot \text { econom_comp }_{i t}+\alpha_{2} \cdot \text { non }_{f i n_{\text {dec }} c_{i t}}+\varepsilon_{i t} \\
& E P S_{i t}=\alpha_{0}+\alpha_{1} \cdot g_{0 v_{-}} \operatorname{comp}_{i t}+\alpha_{2} \cdot \text { non }_{\text {fin }_{\text {declit }}}+\varepsilon_{i t}
\end{aligned}
$$

where $i=1 \ldots 60$ represents the 60 companies in the sample, $t=1,2, \ldots, T$ represents the time (period 2017-2019), $\alpha \_i$ are the parameters of the model; EPS represents the FP; ESEG, 【sust_comp】_econom_comp, gov_comp represent the non-financial disclosure index and its components; non_fin_decleste the existence of the non-financial statement codified by 1-yes, 0 -no; $\varepsilon$ _it are model errors.

When applying panel models, it is important to decide the type of model with fixed effects or random effects. Therefore, it must be decided whether these effects are treated as fixed (FEM) or random (REM), which requires the application of the Hausman test. The Hausman test, in the first phase, involves estimating a model with random effects. A high value of chisquare $\left(\chi^{2}\right)$ statistic of the Hausman test, corresponding to a $p$-value probability (prob.) lower than the significance threshold $\alpha$ of 0.05 , leads to significant differences between the coefficients, which requires the rejection of random effects as inconsistent and it is found that the panel estimation based on fixed effects is more appropriate. In the case of a relatively low value of the test (accompanied by a high $p$-value probability), it determines the approach of the random effects models. In the analysis based on panel data, homoskedasticity is a basic hypothesis, which must be verified. The White test was used to test the homoskedasticity hypothesis while the autocorrelation of errors in model estimation was tested applying Durbin-Watson statistics. The existence of collinearity can be corrected using the generalized least squares method and establishing the validity of the model envisages the application of the Fisher test.

\section{Results of performance mapping using TSCA}

TSCA was used to identify homogenous groups of companies in terms of four dimensions: non-financial disclosure degree, the existence of non-financial statement, FP, but also the industry type. First, the comparative analysis of the solution with a maximum number of clusters was performed, examining the different groups of companies. For both years, 2017 
and 2019, the optimal number of identified clusters was 2, for which the silhouette measure of cohesion and separation was 0.7 in both years, being relatively close to 1 . Second, the results of clustering analysis were evaluated through the industry type. In 2017, cluster 1 represents $26.7 \%$ of the total observations totaling 16 companies, while in 2019 there is an increase in the size of cluster 1 which now represents $41.7 \%$ ( 25 companies). Cluster 2 is the largest in 2017 totaling 44 companies, but it decreases to 58.3\% (35 companies) in 2019 (Figure 2), which marks an improvement in non-financial but also $\mathrm{FP}$ of 9 companies that moved in two years in the cluster of performing companies.

Regarding the importance of predictors, there is a small decrease in this importance in 2019 compared to 2017. Thus, the greatest importance is allocated to the variable aimed at the existence of non-financial statements, followed by ESEG Dind $x$ and by EPS. Cluster 1 consists of companies that have reported the existence of non-financial statements in $100 \%$ of cases and have a high degree of non-financial disclosure but, also a fairly good FP. At the level of 2017, the average value of ESEG Dind $x$ was 73.47 (median ESEG Dind $x=82.41$ ), registering an average to a high degree of disclosure of non-financial information, with a fairly high FP (mean $\mathrm{EPS}=4.18$, median EPS $=0.37$ ). Thus, in the cluster of high-performing companies, $50 \%$ of them register high values of non-financial disclosure degree (over 82.41) and high FP (for which EPS is higher than 0.37). Observed at the level of 2019, cluster 1 now made up of 25 companies, still has the characteristic presence of the non-financial statement in $100 \%$ of cases, but also a degree of non-financial disclosure that remains high (average ESEG Dindx $=71.66$, median ESEG Dindx $=76.78$ ), even if there is a slight decrease compared to 2017. In contrast, the FP of companies in the cluster registered a notable decline over the two years as the EPS indicator reduced its value by almost 3 times (EPS average $=1.83$, EPS median $=0.05$ ).
2017
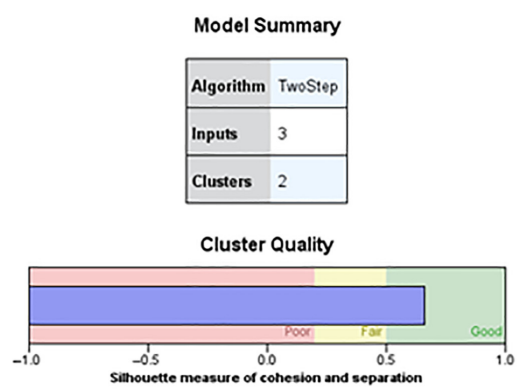

2019

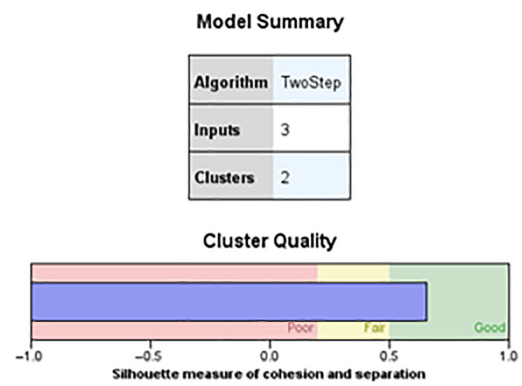

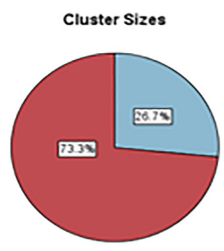

Clustor
昌:
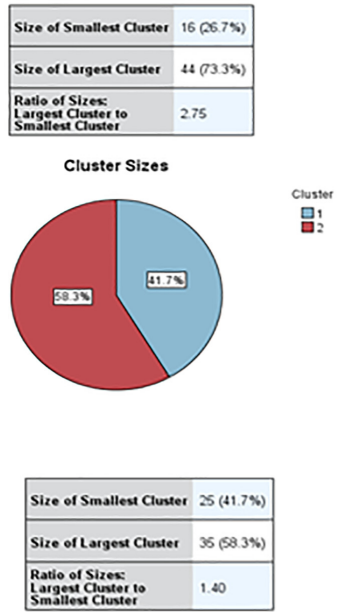

Figure 2. Size of clusters 
$\mathrm{K}$

51,13

106

Observed in 2017, cluster 2 consists of companies that have not reported a non-financial statement and have not registered a high degree of non-financial disclosure (average ESEG Dind $x=37.65$, median ESEG Dind $x=38.86$ ) and also, recorded poor FP (mean EPS $=-0.56$, median EPS $=0.11$ ). Thus, in this cluster, half of the companies have a relatively modest degree of non-financial disclosure (only $50 \%$ of them have a degree higher than 38.86 ) but also a relatively low $\mathrm{FP}$, with $50 \%$ of companies registering $\mathrm{EPS}$ values, greater than 0.11 ). Cluster 2 , observed in 2019, consists entirely of companies that have not reported a non-financial statement and have a relatively low degree of non-financial disclosure (average ESEG $\operatorname{Dind}=37.64$, median ESEG Dind $x=33.14$ ) but also a low FP (average EPS $=-0.12$, median EPS $=0.05$ ). Thus, only half of companies in this cluster registered a non-financial disclosure degree higher than 37.64 and FP higher than 0.05 . Therefore, cluster 1 can be interpreted in terms of financially and non-financially efficient outlets, while cluster 2 targets companies with modest performance. Analyzed in dynamics, both clusters register in $2019 \mathrm{a}$ decrease in performance on its components. According to Figure 3, in 2019 there is a migration of 9 companies from the initial cluster 2 (2017) to cluster 1, which recorded an improvement in non-financial disclosure, non-financial statement but also, in terms of FP.

It is interesting to analyze the composition of clusters in terms of industry type. If the companies in cluster 1 mainly come from manufacturing and transportation industries, in cluster 2 companies are from the manufacturing industry followed by constructions, hotels and restaurants. The results of the Kruskal-Wallis test (Table 1) highlighted differences between the clusters depending on the industry, only for 2017 (Asymp.Sig $<0.031$ ), while for 2019 they refute such differences (Figure 4).

In turbulent times (Basile et al., 2021), the created value by companies from the same business network increases if there is an integrated approach and this becomes more obvious for companies that have significantly improved their performance after joining the business network. Thus, the weaker members of the group in a volatile, uncertain, complex and ambiguous environment can more easily survive and increase their performance following the growing trend of the competitive companies in the sample.

\section{Results of the correlation analysis EPS-ESEG Dindx}

Analyzing FP of sampled companies there is a decrease in average from 0.70 in 2017 to 0.49 in 2018 and 0.69 in 2019. Also, there was an increase in the share of companies that registered the non-financial statement, from $27 \%$ in 2017 to $42 \%$ in 2019 (Figure 5).

The correlation analysis between ESEG Dindx, its components and FP of companies for each of the three years, highlighted the presence of direct but weak links in intensity (with values of Pearson coefficient that is up to 0.30 ) but statistically significant at the threshold of $10 \%$ between ESEG Dindx, its first component (C1) and FP, valid for all three years. Therefore, the research leads to the validation only of $\mathrm{H} 1$ and $\mathrm{H} 1 \mathrm{a}$ and the invalidation of $\mathrm{H} 1 \mathrm{~b}$ and $\mathrm{H1c}$ (Table 2).

H2 was tested using Spearman and Kendall correlation coefficients and the potential differences between the FP depending on the existence of non-financial statements were highlighted using the Mann-Whitney test. The correlation analysis based on the values of the Spearman and Kendall coefficients highlighted direct links of low to medium intensity, but statistically significant at the threshold of $1 \%$ between the existence of non-financial statement and company's FP, valid only for 2017 and 2018, for 2019 the coefficients are no longer statistically significant. Therefore, $\mathrm{H} 2$ is only partially validated, at the level of 2017 and 2018 (Table 3).

Results of the Mann-Whitney test confirmed the above results and revealed the significant differences between the group of companies with low and high FP in terms of nonfinancial statements (Asymp.Sig <5\%) for 2017 and 2018. For 2019, the results are invalidated by the high value of the probability associated with the statistical test (Table 4). 


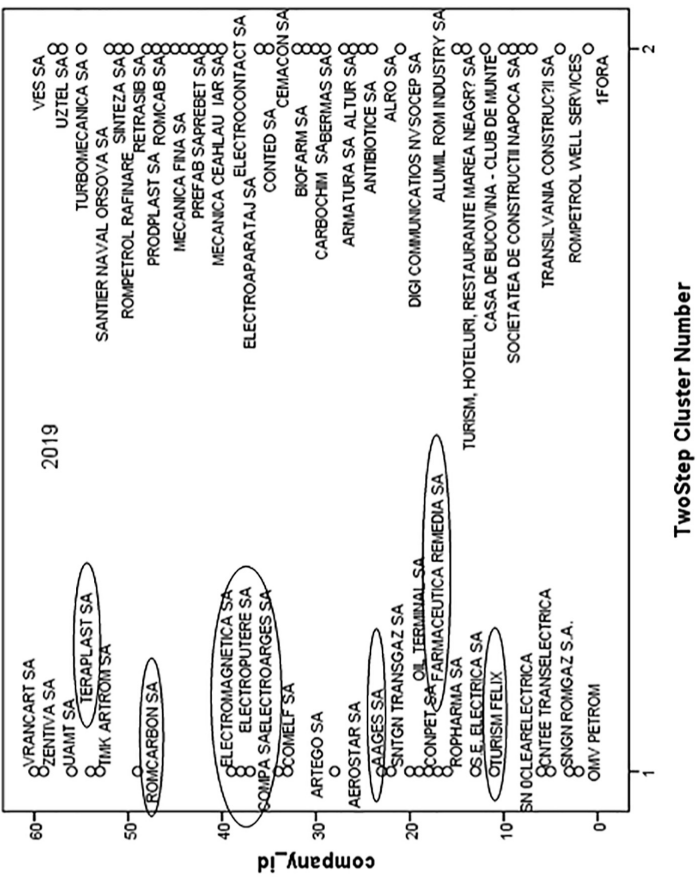

Performance mapping
through ESEG
Dind $x$

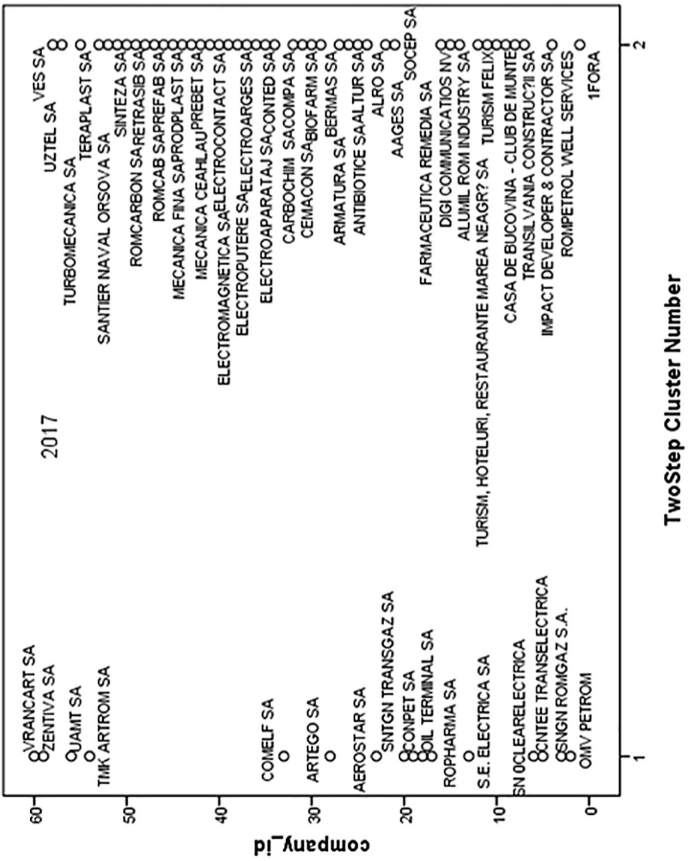

Figure 3. Clusters dynamics 
$\mathrm{K}$

51,13

Ranks

\begin{tabular}{llrr} 
& Industry_code & Mean & $\begin{array}{c}\text { Mank } \\
\text { rank }\end{array}$ \\
\hline \multirow{2}{*}{$\begin{array}{l}\text { Two-step cluster number } \\
2017\end{array}$} & Extractive industry & 4 & 23.50 \\
& Production and supply of electricity and heat, gas, hot water and air & 2 & 8.50 \\
& conditioning & 3 & 38.50 \\
& Constructions & 3 & 38.50 \\
& Hotels and restaurants & 2 & 23.50 \\
& Professional scientific and technical activity & 3 & 28.50 \\
& Wholesale and retail trade & 4 & 16.00 \\
& Transport and storage & 39 & 33.12
\end{tabular}

Test statistics ${ }^{\mathrm{a}, \mathrm{b}}$

Two-step cluster number 2017

\begin{tabular}{llcr}
\hline $\begin{array}{l}\text { Chi-square } \\
\text { df }\end{array}$ & & 15.453 \\
Asymp. Sig & & 7 & 0.031 \\
\hline Ranks & & & Mean \\
& & $N$ & rank \\
\hline & Industry_code & 4 & 28.00 \\
Two-step cluster number & Extractive industry & 2 & 13.00 \\
2019 & Production and supply of electricity and heat, gas, hot water and air & 2 & 43.00 \\
& conditioning & 3 & 33.00 \\
& Constructions & 3 & 28.00 \\
& Hotels and restaurants & 2 & 23.00 \\
& Professional scientific and technical activity & 3 & 20.50 \\
& Wholesale and retail trade & 4 & 32.23
\end{tabular}

Test statistics ${ }^{\mathrm{a}, \mathrm{b}}$

Two-step cluster number 2019

Chi-square

df

Asymp. Sig

8.195

7

0.316
Table 1.

Kruskal-Wallis test results

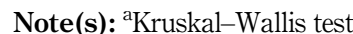

${ }^{\mathrm{b}}$ Grouping variable: industry_code

The impact analysis tested under $\mathrm{H} 3$ and $\mathrm{H} 4$ aimed at estimating four regression models on panel data, one for the three components of the ESEG Dind $x$ and the fourth that included the composite index together with the non-financial statement. In the econometric models, the hypothesis of individual effects and/or random effects was accepted based on the results of the Hausman test (Table 5) whose probabilities were in the case of all models above the $10 \%$ threshold. Also, the empirical results of the Breusch-Pagan Lagrange multiplier (LM) test for random effects showed in the case of the four models the refutation of the null hypothesis according to which there are no significant differences along with the units in the sample (no panel effect), proving the existence random effects in the analysis.

Results highlighted the positive and statistically significant impact at the threshold of $10 \%$ of the ESEG Dindx, but also of its sustainability component, on FP measured by EPS, 


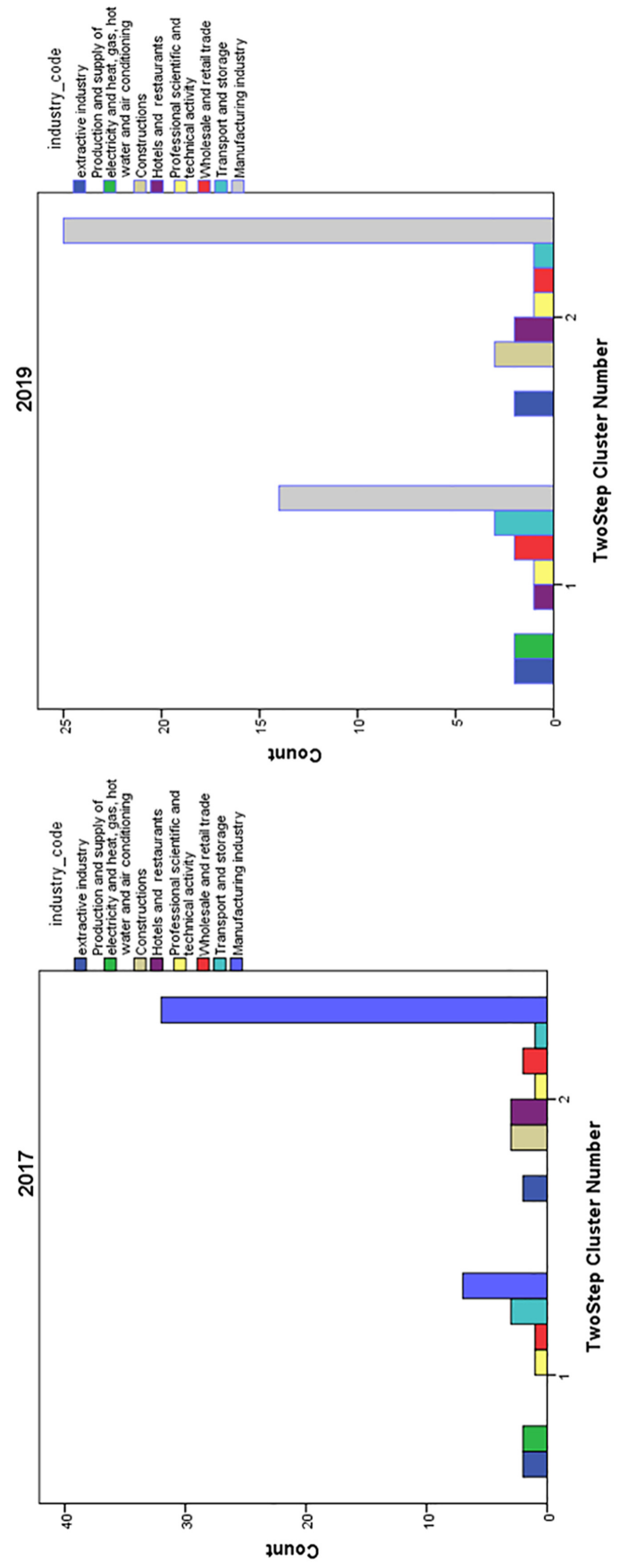

Performance mapping
through ESEG

$\operatorname{Dindx}$

109

Figure 4.

Clusters structure by industries 
$\mathrm{K}$

51,13

\section{0}

Figure 5.

Distribution of EPS and non-financial statement

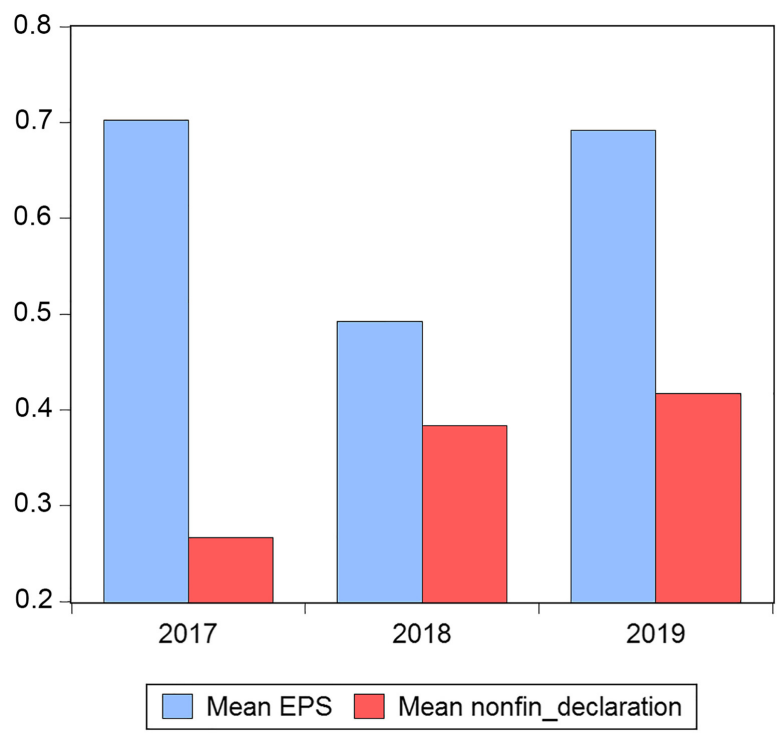

\begin{tabular}{|c|c|c|c|c|c|c|}
\hline \multicolumn{2}{|l|}{ Correlations } & \multirow{2}{*}{$\begin{array}{c}\text { ESEG2017 } \\
0.278^{*} \\
0.032 \\
60\end{array}$} & \multirow{2}{*}{$\begin{array}{c}\text { C1_2017 } \\
0.264^{*} \\
0.042 \\
60\end{array}$} & \multirow{2}{*}{$\begin{array}{c}\text { C2_2017 } \\
0.036 \\
0.786 \\
60\end{array}$} & \multirow{2}{*}{$\begin{array}{c}\text { C3_2017 } \\
0.195 \\
0.136 \\
60\end{array}$} & \multirow{2}{*}{$\begin{array}{c}\text { EPS_2017 } \\
1 \\
60\end{array}$} \\
\hline EPS_2017 & $\begin{array}{l}\text { Pearson correlation } \\
\text { Sig. (2-tailed) } \\
N\end{array}$ & & & & & \\
\hline Correlations & & ESEG2018 & C1_2018 & C2_2018 & C3_2018 & EPS_2018 \\
\hline EPS_2018 & $\begin{array}{l}\text { Pearson correlation } \\
\text { Sig. (2-tailed) } \\
N\end{array}$ & $\begin{array}{l}0.264^{*} \\
0.041 \\
60\end{array}$ & $\begin{array}{l}0.250 \\
0.054 \\
60\end{array}$ & $\begin{array}{l}0.008 \\
0.950 \\
60\end{array}$ & $\begin{array}{l}0.139 \\
0.288 \\
60\end{array}$ & $\begin{array}{r}1 \\
60\end{array}$ \\
\hline Correlations & & ESEG2019 & C1_2019 & C2_2019 & C3_2019 & EPS_2019 \\
\hline EPS_2019 & $\begin{array}{l}\text { Pearson correlation } \\
\text { Sig. (2-tailed) } \\
N\end{array}$ & $\begin{array}{l}0.226 \\
0.083 \\
60\end{array}$ & $\begin{array}{l}0.229 \\
0.078 \\
60\end{array}$ & $\begin{array}{c}-0.045 \\
0.732 \\
60\end{array}$ & $\begin{array}{l}0.129 \\
0.326 \\
60\end{array}$ & $\begin{array}{r}1 \\
60\end{array}$ \\
\hline
\end{tabular}

Note(s): **Correlation is significant at the 0.01 level (2-tailed)

*Correlation is significant at the 0.05 level (2-tailed). $N=$ number of selected companies being 60 companies We used italics to highlight the statistical significance of the correlation between ESEG Dindx, its first component (C1) and FP (Sig. being less than the 10\% significance level threshold) for each of the three years. It is observed in 2017, the presence of direct links, weak in intensity (with values of the Pearson coefficient of up to 0.30), but statistically significant at the threshold of $5 \%$ is between ESEG Dindx, its first component (C1) and FP. In 2018, the direct connection, weak in intensity, but statistically significant at the $5 \%$ threshold, is only

Table 2.

Correlation analysis ESEG Dindx-EPS between ESEG Dindx and FP. The table does not show statistically significant links at the $1 \%$ threshold. We can therefore state, with a probability of $90 \%$, for each of the three years analyzed, that between ESEG Dindx, its first component (C1) and FP there are direct links of low intensity 


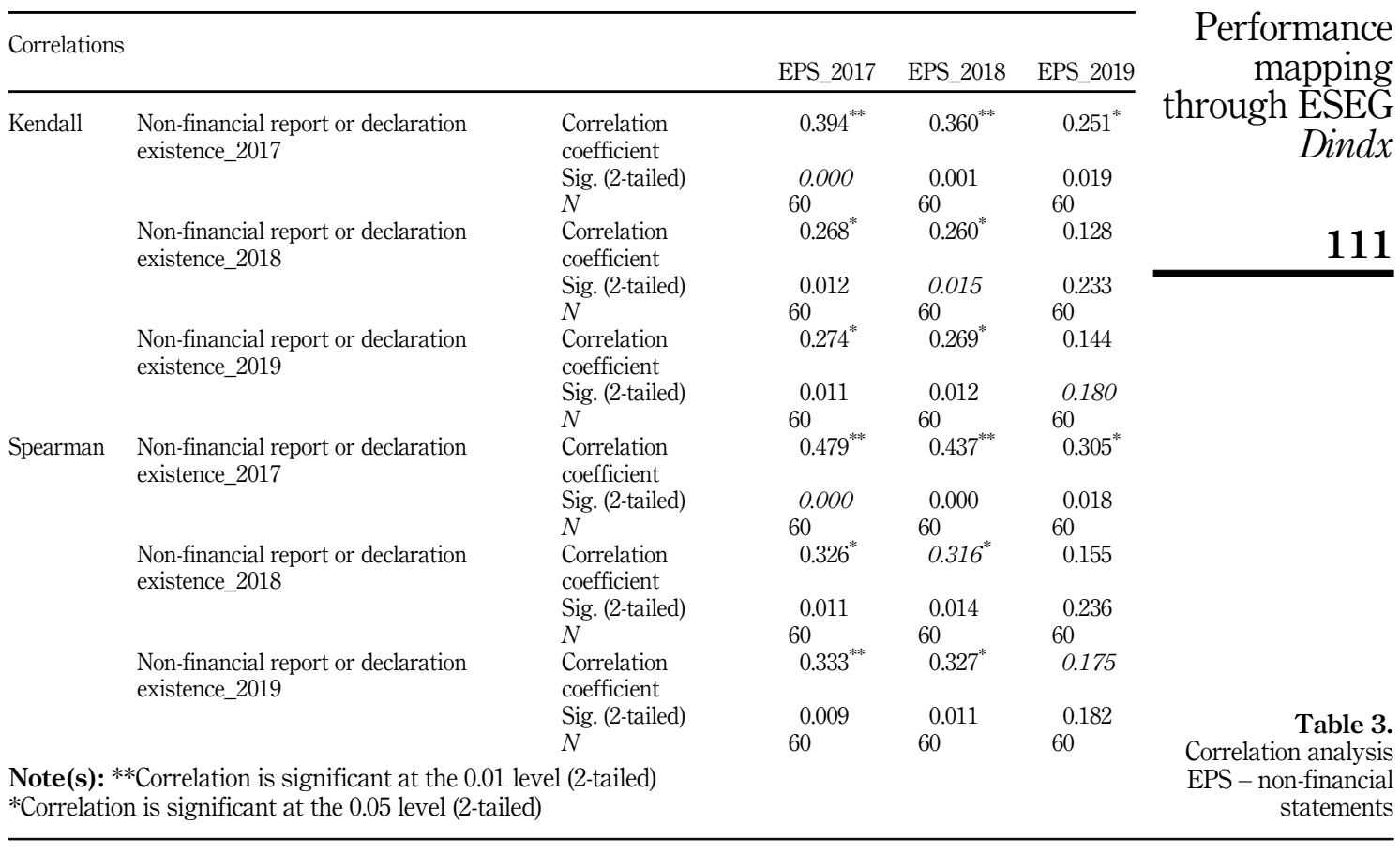

leading to the validation of $\mathrm{H} 3$ and $\mathrm{H} 3 \mathrm{a}$, but invalidating $\mathrm{H} 3 \mathrm{~b}$ and $\mathrm{H} 3 \mathrm{c}$ due to the lack of significance of the coefficients of models III and IV. Also, the existence of non-financial statements does not show a significant impact on the company's FP in all four models (the probabilities related to the coefficients being much higher than the $10 \%$ threshold), leading to the invalidation of $\mathrm{H} 4$. All estimated models are valid, prob. (F-state.) is below 0.05 , estimators were estimated to control potential heteroskedasticity by estimating robust standard errors. The results of the statistical testing process are summarized and presented below in Table 6 .

\section{Conclusion, limits and practical implications}

Results of the first stage of the research revealed two clusters of companies, where the existence of non-financial statements, ESEG Dindx and proxy of FP, represent the variables in order of importance. Therefore, cluster 1 shows financially and non-financially efficient outlets, while cluster 2 targets companies with modest performance. Analyzed in dynamics, both clusters register in 2019 a decrease in performance on its components. Also, in 2019 several companies moved from the initial cluster 2 (2017) to cluster 1, recording an improvement in non-financial disclosure, non-financial statement publication but also in terms of FP. Analysis of the composition of clusters by industries through the KruskalWallis test highlighted differences between the two clusters of companies, only for 2017.

In the second stage of the research using parametric and nonparametric correlation and regression analysis based on panel data we found a direct, although weak in intensity but statistically significant link between ESEG Dindx, its sustainability component and FP of companies, valid for all three years. Also, the results proved there is a direct link of low intensity to average, but statistically significant between the existence of non-financial statements and FP of companies, valid only for 2017 and 2018. 
$\mathrm{K}$

51,13
Ranks

\begin{tabular}{ccccc} 
& Non-financial report or declaration existence_2017 & $N$ & Mean rank & Sum of ranks \\
\hline EPS_2017 & 0 & 44 & 25.50 & 1122.00 \\
& 1 & 16 & 44.25 & 708.00 \\
& Total & 60 & & \\
\hline
\end{tabular}

Test statistics ${ }^{\mathrm{a}}$

EPS_2017

Mann-Whitney $U$

Wilcoxon $W$

132.000

1122.000

$-3.678$

$Z$

Asymp. Sig. (2-tailed)

0.000

Note(s): ${ }^{\mathrm{G} G r o u p i n g}$ variable: non-financial report or declaration existence_2017

\begin{tabular}{lcccc}
\hline Ranks & & & \\
& Non-financial report or declaration existence_2018 & $N$ & Mean rank & Sum of ranks \\
\hline EPS_2018 & 0 & 37 & 26.19 & 969.00 \\
& 1 & 23 & 37.43 & 861.00 \\
& Total & 60 & & \\
\hline
\end{tabular}

Test statistics ${ }^{\mathrm{a}}$

EPS_2018

Mann-Whitney $U$

266.000

Wilcoxon $W$

969.000

Z

$-2.425$

Asymp. Sig. (2-tailed)

0.015

Note(s): ${ }^{\mathrm{a} G r o u p i n g}$ variable: non-financial report or declaration existence_2017

\begin{tabular}{lcccc}
\hline Ranks & Non-financial report or declaration existence_2019 & $N$ & Mean rank & Sum of ranks \\
\hline \multirow{2}{*}{ EPS_2019 } & 0 & 35 & 27.94 & 978.00 \\
& 1 & 25 & 34.08 & 852.00 \\
& Total & 60 & & \\
\hline
\end{tabular}

Test statistics ${ }^{\mathrm{a}}$

EPS_2019

Mann-Whitney $U$

Wilcoxon $W$

978.000

$Z$

Table 4.
Empirical results of Asymp. Sig. (2-tailed)

$-1.342$

Note(s): ${ }^{\mathrm{a} G r o u p i n g}$ variable: non-financial report or declaration existence_2018

The results are in line with those of previous studies in terms of disclosure behavior in correlation with performance for the first year of the adoption of mandatory non-financial reporting requirements, also indicating the existence of a link, weak in intensity, between the sustainability component of disclosure index and FP, both before and after the adoption of regulations. However, the mixed findings invite further in-depth research.

The main limits of the study can be found in selected indicators, the short period time, disclosure metrics and selected companies. However, the practical implications are worth 


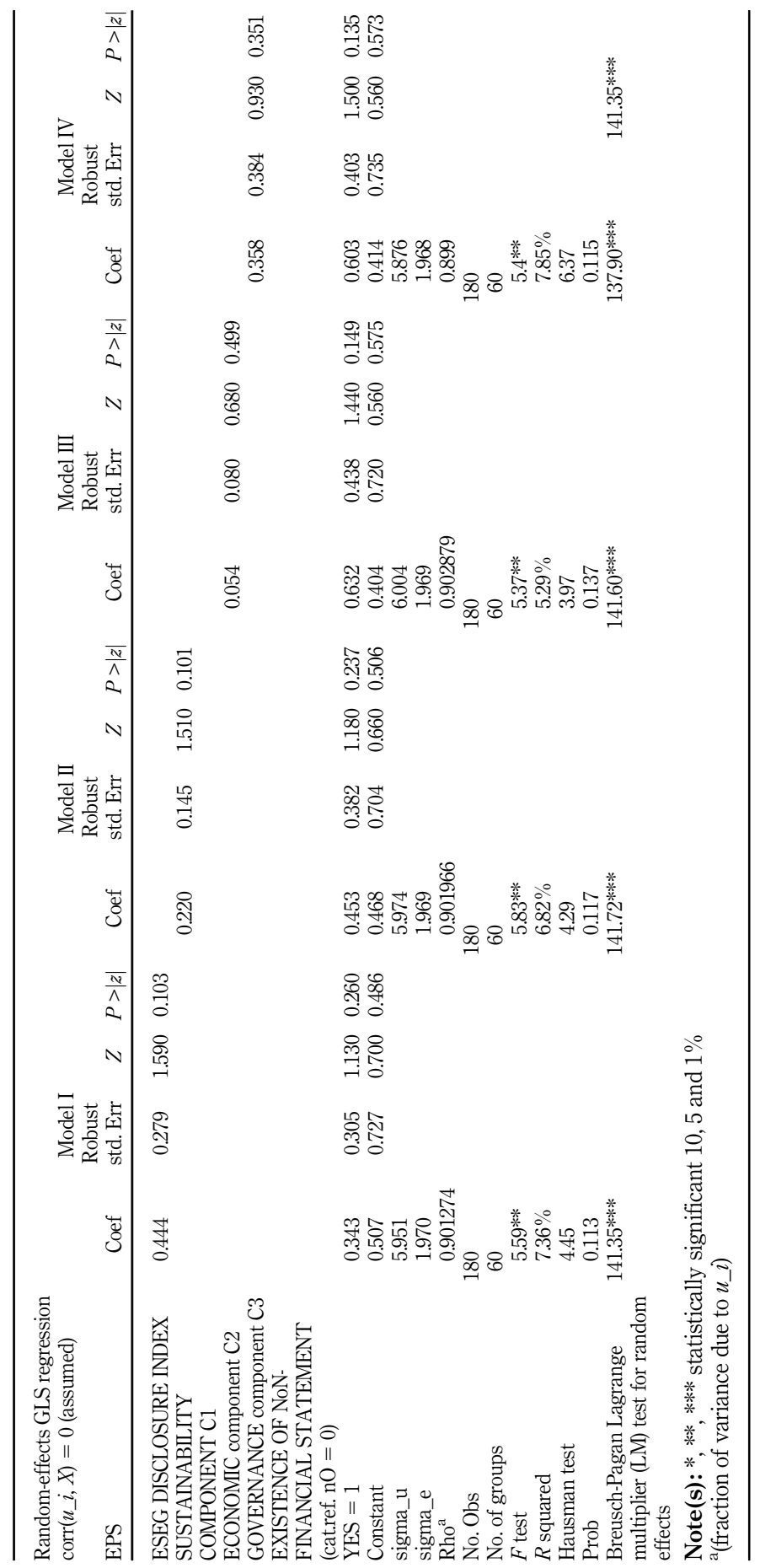

Performance mapping through ESEG Dindx

113

Table 5. Empirical results of panel data regression analysis 
H1b: There is a positive correlation between the economic component of ESEG Dindx and EPS

H3: There is a significant impact of ESEG Dindx on EPS

validated

H3a: There is a significant impact from the sustainability component of ESEG Dindx on EPS Validated

Table 6.

Hypotheses testing results
H3b: There is a significant impact from the economic component of ESEG Dindx on EPS

H3c: There is a significant impact from the governance component of ESEG Dindx on EPS

H4: There is a significant impact of the non-financial statements on EPS
Invalidated

Invalidated

Invalidated

considering from the perspective of finding new managerial tools that can better shape the relationship between ESEG disclosures and FP.

The present study supports the idea of improving the link between non-financial reporting and FP through a composite disclosure index that can be a valuable managerial instrument in optimizing performance indicators, sustainable development and also allowing comparative analyzes between companies, industries and their ranking. Developing such a managerial tool can represent a real opportunity to increase stakeholders' confidence in the company's business practices.

Future research will focus on extending the investigated period, measuring FP based on the composite index, expanding the study on SMEs and predicting disclosure behavior using neural networks.

\section{References}

Alsayegh, M.F., Rahmnan, R.A. and Homayoun, S. (2020), "Corporate economic, environmental, and social sustainability performance transformation through ESG disclosure”, Sustainability, Vol. 12 No. 9, p. 3910, doi: 10.3390/su12093910.

Andreano, M.S., Benedetti, R., Mazzitelli, A., Piersimoni, F. and Di Fatta, D. (2020), "How interconnected SMEs in business cluster survive the economic crisis", Kybernetes, Vol. 50 No. 7, pp. 2001-2020, doi: 10.1108/K-06-2018-0282.

Artene, A., Bunget, O.C., Dumitrescu, A.C., Domil, A.E. and Bogdan, O. (2020), "Non-financial information disclosures and environmental protection-evidence from Romania and Greece", Forests, Vol. 11 No. 8, p. 814, doi: 10.3390/f11080814.

Bătae, O.M., Dragomir, V.D. and Feleagă, L. (2021), "The relationship between environmental, social, and financial performance in the banking sector: a European study", Journal of Cleaner Production, Vol. 290, 125791, doi: 10.1016/j.jclepro.2021.125791.

Basile, G., Andreano, M.S., Martiniello, L. and Mazzitelli, A. (2021), "Drivers of performance in a complex environment: holonic approach and Italian business network contracts", Kybernetes, Vol. 50 No. 7, pp. 2042-2059, doi: 10.1108/K-07-2018-0410.

Beleneși, M., Bogdan, V. and Popa, D.N. (2021), "Disclosure dynamics and non-financial reporting analysis. The case of Romanian listed companies”, Sustainability, Vol. 13 No. 9, p. 4732, doi: 10.3390/su13094732.

Boakye, D.J., Tingbani, I., Ahinful, G.S. and Nsor-Ambala, R. (2021), "The relationship between environmental management performance and financial performance of firms listed in the Alternative Investment Market (AIM) in the UK", Journal of Cleaner Production, Vol. 278, 124034, doi: 10.1016/j.jclepro.2020.124034. 
Boloş, M.I., Bradea, I.A. and Delcea, C. (2021), "Optimization of financial asset neutrosophic portfolios", Mathematics, Vol. 9, p. 1162, doi: 10.3390/math9111162.

Borodin, A., Shash, N., Panaedova, G., Frumina, S., Kairbekuly, A. and Mityushina, I. (2019), "The impact of the publication of non-financial statements on the financial performance of companies with the identification of intersectoral features", Entrepreneurship and Sustainability Issues", VsI Entrepreneurship and Sustainability Center, Vol.7 No. 2, pp. 1666-1685, doi: 10.9770/jesi.2019.7.2(61.

Broadstock, D., Chan, K., Cheng, L. and Wang, X. (2021), "The role of ESG performance during times of financial crisis: evidence from COVID-19 in China", Finance Research Letters, Vol. 38, 101716, doi: 10.1016/j.frl.2020.101716.

Campbell, J.L. (2007), "Why would corporations behave in socially responsible ways? An institutional theory of corporate social responsibility", Academy of Management Review, Vol. 32 No. 3, pp. 946-967, doi: 10.5465/amr.2007.25275684.

Cho, C.H. and Patten, D.M. (2007), "The role of environmental disclosures as tools of legitimacy: a research note", Accounting, Organizations and Society, Vol. 32 No. 7, pp. 639-647, doi: 10.1016/j. aos.2006.09.009.

Cho, C.H., Michelon, G., Patten, D.M. and Roberts, R.W. (2015), "CSR disclosure: the more things change. ..?", Accounting, Auditing and Accountability Journal, Vol. 28, pp. 14-35, doi: 10.1108/ AAAJ-12-2013-1549.

Clarkson, P.M., Overell, M.B. and Chapple, L. (2011a), "Environmental reporting and its relation to corporate environmental performance”, Abacus, Vol. 47 No. 1, pp. 27-60, doi: 10.1111/j.14676281.2011.00330.x.

Clarkson, P.M., Li, Y., Richardson, G.D. and Vasari, F.P. (2011b), "Does it really pay to be green? Determinants and consequences of proactive environmental strategies", Journal of Accounting and Public Policy, Vol. 30 No. 2, pp. 122-144, doi: 10.1016/j.jaccpubpol.2010.09.013.

Connelly, B.L., Certo, S.T., Ireland, R.D. and Reutzel, C.R. (2011), "Signaling theory: a review and assessment”, Journal of Management, Vol. 37 No. 1, pp. 39-67, doi: 10.1177/0149206310388419.

Cormier, D., Magnan, M. and Van Velthoven, B. (2005), "Environmental disclosure quality in large German companies: economic incentives, public pressure or institutional conditions?", European Accounting Review, Vol. 14 No. 1, pp. 3-39, doi: 10.1080/0963818042000339617.

Dainelli, F., Bini, L. and Giunta, F. (2013), "Signaling strategies in annual reports: evidence from the disclosure of performance indicators", Advances in Accounting, Vol. 29 No. 2, pp. 267-277, doi: 10.1016/j.adiac.2013.09.003.

Deegan, C. (2006), Financial Accounting Theory, McGraw-Hill, Sydney.

Deegan, C.M. (2019), "Legitimacy theory: despite its enduring popularity and contribution, time is right for a necessary makeover", Accounting, Auditing and Accountability Journal, Vol. 32, pp. 2307-2329, doi: 10.1108/AAAJ-08-2018-3638.

Dospinescu, O. and Dospinescu, N. (2018), “A profitability regression model of Romanian Stock Exchange's Energy Companies", Proceedings of the IE 2018 International Conference, available at: www. conferenceie.ase.rohttps://www.researchgate.net/publication/325847421_A_PROFITABILITY_ REGRESSION_MODEL_OF_ROMANIAN_STOCK_EXCHANGES_ENERGY_COMPANIES.

Dospinescu, N. and Dospinescu, O. (2019), "A profitability regression model in financial communication of Romanian stock exchange's companies", EcoForum, Vol. 8 No. 1, 884, available at: http://www.ecoforumjournal.ro/index.php/eco/article/view/884.

European Union (2014), "Directive 2014/95/UE of the European Parliament and of the Council of 22 October 2014 amending Directive 2013/34/UE as regards sisclosure of non-financial and diversity information by certain large undertakings and groups", available at: https://eur-lex. europa.eu/legal-content/EN/TXT/?uri=CELEX\%3A32014L0095 (accessed 25 January 2021).

Farag, H., Meng, Q. and Mallin, C. (2015), "The social, environmental and ethical performance of Chinese companies: evidence from the Shanghai Stock exchange", International Review of Financial Analysis, Vol. 42, pp. 53-63, doi: 10.1016/j.irfa.2014.12.002.
Performance mapping through ESEG $\operatorname{Dindx}$ 
$\mathrm{K}$

51,13

Gaganis, C., Pasiouras, F., Tasiou, M. and Zopounidis, C. (2021), "CISEF: a composite index of social, environmental and financial performance”, European Journal of Operational Research, Vol. 291 No. 1, pp. 394-409, doi: 10.1016/j.ejor.2020.09.035.

Grinblatt, M. and Hwang, C.Y. (1989), "Signaling and the pricing of new issues", Journal of Finance, Vol. 44 No. 2, pp. 393-420, doi: 10.1111/j.1540-6261.1989.tb05063.x.

Guthrie, J. and Parker, L.D. (1989), "Corporate social reporting: a rebuttal of legitimacy theory", Accounting Business Research, Vol. 19, pp. 343-352, doi: 10.1080/00014788.1989.9728863.

Healy, P.M. and Palepu, K.G. (2001), "Information asymmetry, corporate disclosure, and the capital markets: a review of the empirical disclosure literature", Journal of Accounting and Economics, Vol. 31 Nos 1-3, pp. 405-440, doi: 10.1016/S0165-4101(01)00018-0.

Horvathova, E. (2010), "Does environmental performance affect financial performance? A metaanalysis", Ecological Economics, Vol. 70 No. 1, pp. 52-59, doi: 10.1016/j.ecolecon.2010.04.004.

Huang, D.Z.X. (2021), "Environmental, social and governance (ESG) activity and firm performance: a review and consolidation", Accounting and Finance, Vol. 61, pp. 335-360, doi: 10.1111/ acfi.12569.

Hummel, K. and Schlick, C. (2016), "The relationship between sustainability performance and sustainability disclosure - reconciling voluntary disclosure theory and legitimacy theory", Journal of Accounting and Public Policy, Vol. 35 No. 5, pp. 455-476, doi: 10.1016/j.jaccpubpol. 2016.06.001.

Imbrescu, C.M. and Hațegan, C.D. (2017), "Ex-ante study about disclosure of non-financial information by Romanian companies from agriculture and manufacture of food products", Journal of Economics and Business Research, Vol. 23 No. 2, pp. 45-58.

Jensen, M.C. and Meckling, W.H. (1976), "Theory of the firm: managerial behavior, agency costs and ownership structure", Journal of Financial Economics, Vol. 3 No. 4, pp. 305-360, doi: 10.1016/ 0304-405X(76)90026-X.

Kuo, T.C., Chen, H.M. and Meng, H.M. (2021), "Do corporate social responsibility practices improve financial performance? A case study of airline companies", Journal of Cleaner Production, Vol. 310, 127380, doi: 10.1016/j.jclepro.2021.127380.

Luo, L. (2019), "The influence of institutional contexts on the relationship between voluntary carbon disclosure and carbon emission performance", Accounting and Finance, Vol. 59 No. 2, pp. 1235-1264, doi: 10.1111/acfi.12267.

Man, M. and Bogeanu-Popa, M.M. (2020), "Impact of non-financial information on sustainable reporting of organisations' performance: case study on the companies listed on the bucharest stock exchange", Sustainability, Vol. 12 No. 6, p. 2179, doi: 10.3390/su12062179.

Manes-Rossi, F., Tiron-Tudor, A., Nicolò, G. and Zanellato, G. (2018), "Ensuring more sustainable reporting in Europe using non-financial disclosure - de facto and de jure evidence", Sustainability, Vol. 10 No. 4, p. 1162, doi: 10.3390/su10041162.

Marjanova, T., Sofijanova, E., Davcev, L. and Temjanovski, R. (2017), "Impact of integrated communication on entrepreneurial companies' financial performance: a developing economy”, Financial Environment and Business Development, Eurasian Studies in Business and Economics, Springer International, Vol. 4, pp. 29-41, doi: 10.1007/978-3-319-39919-5_3.

MdNor, N., Shaiful Bahari, N.A., Adnan, N.A., Kamal, S.M.Q.A.S. and Ali, I.M. (2016), "The effects of environmental disclosure on financial performance in Malaysia", Procedia Economics and Finance, Vol. 35, pp. 117-126, doi: 10.1016/S2212-5671(16)00016-2.

Nicolò, G., Zanellato, G. and Tiron-Tudor, A. (2020), "Integrated reporting and European state-owned enterprises: a disclosure analysis pre and post 2014/95/EU”, Sustainability, Vol. 12 No. 5, 1908, doi: 10.3390/su12051908.

Nirino, N., Santoro, G., Miglietta, N. and Quaglia, R. (2021), “Corporate controversies and company's financial performance: exploring the moderating role of ESG practices", Technological Forecasting and Social Change, Vol. 162, 20341, doi: 10.1016/j.techfore.2020.120341. 
O'Donovan, G. (2002), "Environmental disclosures in the annual report: extending the applicability and predictive power of legitimacy theory", Accounting, Auditing and Accountability Journal, Vol. 15 No. 3, pp. 344-371, doi: 10.1108/09513570210435870.

Order of the Minister of Public Finance (2016), "No. 1938/2016 for amending and supplementing accounting regulations", Bucharest, available at: https:/static.anaf.ro/static/10/Anaf/legislatie/ OMFP_1938_2016.pdf (accessed 25 January 2021).

Order of the Minister of Public Finance (2018), No. 3456/2018 for Amending and Supplementing Accounting Regulations, Bucharest, available at: https://static.anaf.ro/static/10/Anaf/legislatie/ OMFP_3456_2018.pdf (accessed 25 January 2021).

Pavlopoulos, A., Magnis, C. and Iatridis, G.E. (2019), "Integrated reporting: an accounting disclosure tool for high quality financial reporting", Research in International Business and Finance, Vol. 49, pp. 13-40, doi: 10.1016/j.ribaf.2019.02.007.

Petitjean,M. (2019), "Eco-friendly policies and financial performance: was the financial crisis a game changer for large US companies?”, Energy Economics, Vol. 80, pp. 502-511, doi: 10.1016/j.eneco.2019.01.028.

Qiu, Y., Shaukat, A. and Tharyan, R. (2016), "Environmental and social disclosures: link with corporate financial performance", The British Accounting Review, Vol. 48 No. 1, pp. 102-116, doi: 10.1016/j. bar.2014.10.007.

Rahman, R.A. and Alsayegh, M.F. (2021), "Determinants of corporate environment, social and governance (ESG) reporting among asian firms", Journal of Risk and Financial Management, Vol. 14 No. 4, p. 167, doi: 10.3390/jrfm14040167.

Rezaee, Z. (2017), "Corporate sustainability: theoretical and integrated strategic imperative and pragmatic approach", The Journal of Business Inquiry, Vol. 16 No. 1, pp. 60-87.

Roberts, R. (1992), "Determinants of corporate social responsibility disclosure: an application of stakeholder theory", Accounting Organizations and Society, Vol. 17, pp. 595-612, doi: 10.1016/ 0361-3682\%2892\%2990015-K.

Sabău-Popa, C.D., Simut, R., Droj, L. and Bențe, C.C. (2020), "Analyzing financial health of the SMES listed in the AERO market of bucharest stock exchange using principal component analysis", Sustainability, Vol. 12 No. 9, p. 3726, doi: 10.3390/su12093726.

Siddique, M.A., Akhtaruzzaman, M., Rashid, A. and Hammami, H. (2021), "Carbon disclosure, carbon performance and financial performance: international evidence", International Review of Financial Analysis, Vol. 75, 101734, doi: 10.1016/j.irfa.2021.101734.

Ştefan, I.O. (2016), "The implications of financial performance on stock exchange indicators of listed companies: empirical evidence for the Romanian capital market”, Audit Financiar, Vol. XIV No. 8, pp. 875-896, doi: 10.20869/AUDITF/2016/140/875.

Tarquinio, L., Posadas, S.C. and Pedicone, D. (2020), "Scoring nonfinancial information reporting in Italian listed companies: a comparison of before and after the legislative decree 254/2016", Sustainability, Vol. 12 No. 10, p. 4158, doi: 10.3390/su12104158.

Tilling, M.V. (2004), "Some thoughts on legitimacy theory in social and environmental accounting", Social and Environmental Accountability Journal, Vol. 24 No. 2, pp. 3-7, doi: 10.1080/0969160X.2004.9651716.

Venturelli, A., Pizzi, S., Caputo, F. and Principale, S. (2020), "The revision of nonfinancial reporting directive: a critical lens on the comparability principle", Business Strategy and the Environment No. 29, pp. 1-14, doi: 10.1002/bse.2598.

Weber, M. (2008), "The business case for corporate social responsibility: a company-level measurement approach for CSR", European Management Journal, Vol. 26 No. 4, pp. 247-261, doi: 10.1016/j.emj. 2008.01.006.

Xie, J., Nozawa, W., Yagi, M., Fujii, H. and Managi, S. (2019), "Do environmental, social, and governance activities improve corporate financial performance?", Business Strategy and the Environment, Vol. 28 No. 2, pp. 286-300, doi: 10.1002/bse.2224.

$\mathrm{Xu}$, J., Liu, F. and Shang, Y. (2021), "R\&D investment, ESG performance and green innovation performance: evidence from China”, Kybernetes, Vol. 50 No. 3, pp. 737-756, doi: 10.1108/K-12-2019-0793.
Performance mapping through ESEG $\operatorname{Dindx}$ 
$\mathrm{K}$

51,13

\section{About the authors}

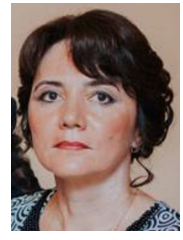

Dorina Nicoleta Popa is an Associate Professor at the Department of Finance and Accounting at the Faculty of Economic Sciences, University of Oradea, Romania. Her research areas are financial and economic analysis, company evaluation and company's economic and financial diagnosis. She is the author and co-author of eight books and over 30 scientific articles in these fields. She has been involved in several national and international grants and research projects. She is also involved in the scientific organization of the international conference held at the faculty for the last years.

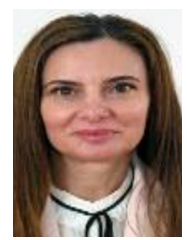

Victoria Bogdan is a Professor habil at the Department of Finance and Accounting at University of Oradea, Romania. Her main research fields are accounting regulation, IFRS, professional accounting judgment and decision making, accounting policies and estimates. She authored and co-authored ten books and over 40 scientific articles, published in Romania, Cyprus, Malta, Croatia, Hungary, Thailand and other countries. She has been involved in several national and international grants and research projects. She is also involved in the scientific organization of the international conference held at the faculty for the last ten years and she is a certified accountant and auditor.

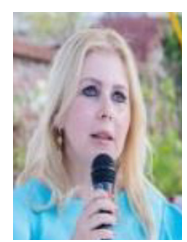

Claudia Diana Sabau Popa, PhD is a Professor Habil of the Faculty of Economic Sciences, University of Oradea, having a doctorate in Finance. She has the position of Vice-Dean of the Faculty of Economic Sciences from University of Oradea. Her scientific work has been materialized in a total of 8 books, over 40 articles published in international specialty journals and many projects funded by structural funds. She also is specialized in financial markets, European finance and corporate finance. Claudia Diana Sabau Popa is the corresponding author and can be contacted at: dianasabaupopa@yahoo.ro

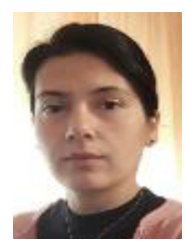

Marioara Belenesi is an Assistant Professor at the Department of Finance and Accounting at the Faculty of Economic Sciences, University of Oradea, Romania. Her research areas are Financial Accounting, IFRS and Financial Analysis. She is co-author of books, textbooks and research papers in these fields. Most of her teaching activities were conducted in these areas until now. She previously published papers in Romania, Thailand, and Portugal. She has presented papers at international conferences on Romania's companies financial reporting practices, accounting policies and performance valuation indicators.

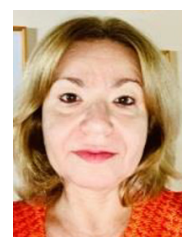

Alina Badulescu is a Professor of Economics and $\mathrm{PhD}$ coordinator in both the field of Economics and of Business Administration at the Faculty of Economic Sciences, University of Oradea, Romania. She has almost 30 years of experience in higher education and economic research, with over 40 articles published in top rated WoS indexed journals and over 30 papers in proceedings of international WoS indexed conferences. She is an editorial member, guest editor and reviewer for more than 40 journals, including $30 \mathrm{WoS}$ indexed journals and international evaluator for research grants and competitions.

For instructions on how to order reprints of this article, please visit our website:

www.emeraldgrouppublishing.com/licensing/reprints.htm

Or contact us for further details: permissions@emeraldinsight.com 